\title{
Spatio-Temporal Analysis of Shoreline Movements along the Coastal Stretch from Bortianor to Winneba, Ghana
}

\author{
Ishmael Yaw Dadson (Ph.D) \\ Department of Geography Education, P. O. Box 25, University of Education, Winneba-Ghana
}

\begin{abstract}
Shoreline movement is largely dependent on the extent of erosion and accretion, thus making it one of the most dynamic geomorphic phenomena along the coast. The study sought to assess the spatio-temporal dynamics of shoreline movements along the coastal stretch between Bortianor in the Greater Accra Region and Winneba in the Central Region of Ghana from 2000 to 2020 . The study used shoreline data mapped from field-based high resolution aerial imagery and Landsat 7 and 8 images. Digital Shoreline Analysis System (DSAS) software 5 was used for the data processing and analysis, with reference to Shoreline Change Envelope, Net Shoreline Movement, End Point Rate, Linear Regression Rate and Weighted Linear Regression. It was observed that the entire shoreline under study generally experienced a continuous retreat than advancement due to the moderate to very high accretion. This notwithstanding, very high erosion was observed on the eastern side of the coast in Fete, leading to an advancement of the shoreline. The study recommends constant monitoring of the coastline by researchers and relevant stakeholders and also the need to put in place protective mechanisms such as sea defenses by the Ministry of Water Resources, Works and Housing to avoid the worse scenarios being experienced in other parts of the Ghanaian coastline.
\end{abstract}

Keywords: shoreline movements, accretion, erosion, shoreline retreat, shoreline advancement

DOI: $10.7176 / \mathrm{JEES} / 11-1-04$

Publication date: January $31^{\text {st }} 2021$

\section{Introduction}

Shoreline movements or changes are the products of wave erosion and accretion. Wave erosion is a major geomorphic process carried out by the sea in any coastal environment. Coastal erosion is the wearing away of land and the removal of beach materials by wave action and tidal currents (Waugh, 1995). Erosion may take the form of long-term losses of sediments and rocks or mainly the temporary redistribution of coastal sediments. Erosion in one location may result in accretion nearby. Erosion and accretion work hand in hand, and that is why, though, erosion occurs continuously, the beach is never deprived of deposited materials (Kuhn \& Shepard 1983).

Some coastal areas may be accreting in the short-term but the general trend is in the direction of the retreating shoreline (Beathey \& Brower, 2002). According to Beathey and Brower (2002), beach erosion is either episodic or sporadic. Beach erosion is episodic when it occurs over a short period, sometimes in hours such as those that are caused by hurricanes or sometimes during a season such as El Nino event. It is sporadic when all areas are not eroded at the same rate during a storm. Some areas have severe erosion during an event while other areas may have much less erosion. Some areas are constantly and rapidly eroding such as the Mississippi Delta Region in the United States of America. The above statement by Beathey and Brower (2002), is a truism since even areas with the same coastal orientation may suffer differently from sea erosion due to other factors such as geology, the direction of the longshore drift and even the extent of anthropogenic activities.

Coastal erosion in Ghana has been a major feature of the shoreline, especially areas stretching from the eastern side of Cape Three Point to the south eastern border with Togo. The vulnerability of the eastern side of Cape Three Point to the south eastern border can be seen from the high loss of mangrove strands through human exploitation and also siltation of lagoons which lead to the loss of its shoreline's protective feature. Another reason for the erosion is the lithology of the stretch which is susceptible to sea erosion and other geomorphic processes. Thus through continuous erosion and accretion, the shoreline advances and retreats. The seriousness of these two most important coastal processes has rendered most coastlines very vulnerable and as a result a number of protective mechanisms have been put in place to restore the coastline in Ghana (Oteng-Ababio, Owusu, \& Appeaning-Addo, 2011).

Researchers have conducted some studies on shoreline movements both in Ghana and elsewhere but little or non-seem to have been done on the Winneba-Bortianor shoreline, and most especially in recent times. Angnuureng et al; (2016) in their study, identified erosion as a major problem along the coastline of Ghana with over 25 erosion hotspots, including parts of this study area. Evadzi et al; (2017) in their study, also estimate the contribution of sea-level rise (SLR) in Ghana over the last decades and provide an estimation of shoreline retreat due to the projections of regional SLR. The study finally makes predictions of shoreline movements in Ghana. Jonah et al; (2016) focuses on the shoreline evolution that occurred along the Elmina, Cape Coast and Moree coast of Ghana using a thirty-eight year period datasets that allowed the authors to discern between what happened between 1974 and 2005, and in the most recent years, between 2005 and 2012. Similar studies have been carried out by Boye et 
al; (2018), Dadson et al; (2016) Oteng Ababio et al; (2011). All these studies were either carried out along the entire coastline of Ghana or limited to the south eastern and part of central-western coastlines. The Bortianor Winneba coastline has not received the desired research in terms of erosion, accretion and shoreline movements yet the impact of erosion and accretion on shoreline movements in this area is a matter for concern since the area harbours a large number of people whose livelihoods are dependent on the sea. There is also a serious threat from erosion because a visit to the area reveals a number of buildings being very close to the sea, especially at Nyanyaano, Senya Bereku, Fete and Winneba hence any movements in the shoreline is likely to have a significant effect on the people. It thus calls for studies to be carried out to unravel the extent of shoreline movements and the impact it is likely to have on such a coastal environment. This study thus is aimed at exploring the extent of shoreline movements in relation to erosion and accretion and the factors that are responsible for such processes. Specifically, the study analyses the extent of shoreline movements at selected locations (in segments) along the coastline between Bortianor and Winneba from the year 2000 to 2020. It is also to analyse the reasons for the extent of erosion and accretion and implications for policy recommendations.

\section{Literature Review}

Shoreline is the boundary between the land and the sea. It is the line of contact between the land and the water body (Alesheikh, Ghorbanali \& Nouri, 2007). Shoreline, which may be used interchangeably with coastline is one of the most important linear features on earth's surface which has a dynamic nature Alesheikh et al., (2007) and constantly changes and moves landward, that is advance or seaward, that is retreat. Shoreline change is thus the variations or movements that occur along the coast causing it to advance towards the land or to retreat further into the sea. Shorelines or coastlines keep changing their shape and position continuously due to dynamic environmental conditions. The change is mainly associated with waves, tides, winds, periodic storms, sea level change, and the geomorphic processes of erosion and accretion and human activities. According to Gibeaut, Hepner, Waldinger, Andrews, Gutierrez, Tremblay \& Smyth, (2001), "the changes are caused by changes in the forces that move the sand, namely wind, waves, and currents and by the supply of sand while short-term and longterm relative sea-level changes also control shoreline movements". Waves, for instance, change the coastline morphology and form the distinctive landforms. The coastline of Ghana like many in the rest of the world has changed over the years in response to changes in the natural environment (Boateng, 2009). Such changes have occurred over a wide range of temporal and spatial scales that reflect influences such as movement of the earth crust, and variations in sea level and climate. The physical shoreline change is also influenced by coastal engineering structures and other human activities.

Shoreline change may occur periodically and may also be a continuous process. Thus to understand and determine the rate of shoreline change along a particular coast, the setting of the shoreline and the supply of sand become important determining factors. Setting, according to Gibeaut, et al (2001), refers to whether a beach is sheltered from waves, adjacent to a tidal or storm channel or next to a jetty or seawall. Gibeaut, et al; (2001) therefore, identify three types of shoreline change, namely, short-term change, long-term change and episodic change.

Short-term shoreline change according to Gibeaut, et al; (2001) is the movements occurring over several seasons to 5 or 10 years. It is shoreline change that occurs over about 10 years or less and that may be in the opposite direction of the long-term trend. It is difficult to understand and predict because it is variable in nature. One portion of the coast may be experiencing retreat while just a few kilometres away stable or advancing conditions may prevail.

Long-term shoreline change, on the other hand, occurs over tens to thousands of years. It is the changing of sea level relative to the land and the increase and decrease in sand supply to the coast that cause the shoreline to retreat or advance over a period of about 50 years or more. Shoreline change, as has been said earlier may not always be a continuous and steady process but may be periodic or episodic. Episodic change is that which occurs in response to a single storm (Gibeaut, et al 2001). Tropical storms, hurricanes, tsunamis and periodic storm surge can move the shoreline landward in a day for several meters as it occurred "during Hurricane Carla in 1961, where foredunes on Mustang Island were eroded back 50 to100 m" (Hayes, 1961, in Gibeaut, et al; (2001). There is often dramatic recovery for months and years following a storm, but it is usually incomplete, and the shoreline remains significantly landward of its pre-storm position. According to Gibeaut, et al; (2001), "even though shoreline change rates are given as annual rates, they must be considered "average" annual rates. This is because a particular shoreline with a long-term retreat rate of $2 \mathrm{~m} / \mathrm{yr}$ would be expected to be $120 \mathrm{~m}$ landward in 60 years yet a single storm, however, could cause much of this movement".

It should also be worth noting that the rate of shoreline change may differ from coast to coast due to differences in natural and anthropogenic characteristics of the various coastlines. For example in the US, shorelines are receding at an average rate of $0.8 \mathrm{~m} / \mathrm{yr}$ yet there are differences among the various coastal regions. For example, erosion rates vary from $0.0 \mathrm{~m} / \mathrm{yr}$ along the Pacific Coast to $0.8 \mathrm{~m} / \mathrm{yr}$ along the Atlantic and $1.8 \mathrm{~m} / \mathrm{yr}$ along the Gulf Coast (May et al., 1983). Dale et al., (1995) agreed with May et al., (1983) when they stated that significantly, 
rates may vary drastically on a local basis where they depend on geology, wave and climate. This means that the nature of rocks found along the coast, the energy of the waves and influence from climate are responsible for different rates of sea erosion and shoreline recession. These notwithstanding, the influence of anthropogenic factors cannot be underestimated. This is an important factor in areas where there are uncontrolled human activities such as sand mining and quarrying. The importance of climate and anthropogenic factors in shoreline erosion is also affirmed by Kuhn \& Shepard (1983), when they concluded that coastal erosion is episodic, site specific, strongly related to meteorological conditions and influenced by human factors.

A major challenge facing the planet Earth and its resource in the next century is the changing climate; its impacts on our life sustaining resources and our ability to adapt to the change (IPCC, 2007). The outcome of many scientific researches indicated that climate change has varying impacts raging from physical, environmental, economic to social dimensions. On coastal regions, the biggest danger, many experts warn, is that climate change is causing sea levels to rise increasingly rapidly. This poses global problems because majority of the world's population lives in coastal areas. A changing global climate combined with intense human activity imposes additional stresses on coastal environments. Although the climate is warming at a global scale, the impacts and the timing of the impacts are highly variable across coastal regions (IPCC, 2007). Some effects, such as rising sea level, are already evident in increased erosion of beaches, more frequent flooding from both rivers and tidal surge, and wetlands converting to open water. The primary driving forces are: sea-level rise, changes in temperature, precipitation, major storm events including waves, winds and currents, and changing ocean circulation patterns. These driving forces interact in complex ways with the landforms and infrastructure that make the coasts particularly vulnerable to many of the impacts of climate change.

In Ghana, different scenarios for the estimation of current and forecasted sea level rise in the Gulf of Guinea are being developed. Trends on Ghana obtained using nationally observed climate data for the period of 1960 to 2000, coupled with regional climate models together with IPCC scenarios indicate that:

- Estimated temperature will continue to rise by on average about $0.6^{\circ} \mathrm{C}, 2^{\circ} \mathrm{C}$ and $3.9^{\circ} \mathrm{C}$ by the year 2020 , 2050 and 2080 respectively.

- Rainfall is predicted to decrease on average by $2.8 \%, 10.9 \%$ and $18.6 \%$ by 2020,2050 and 2080 respectively in all agro-ecological zones except the rainforest zone, where rainfall may increase.

- A projected sea level rise (SLR) of $1 \mathrm{~m}$ by 2100 could see the loss of over $1000 \mathrm{~km}^{2}$ of land, with 132000 people likely to be affected. The east coast is particularly vulnerable to flooding and shoreline recession (UNEP/UNDP, 2012).

Thus, extreme weather conditions will pose risks to businesses and other economic sectors, especially in coastal areas due to sea level rise.

Anthropogenic activities such as employment, recreation, tourism, water-based commerce, energy and mineral production are driving forces of population migration to coastal areas (Heinz, 2000). Coastal population growth in many of the world's deltas, barrier islands and estuaries has led to widespread conversion of natural coastal landscapes to agriculture, aquaculture, silviculture, as well as industrial and residential uses (Valiela, 2006). It has been estimated that $23 \%$ of the world's population lives both within $100 \mathrm{~km}$ distance of the coast and less than $100 \mathrm{~m}$ above sea level, and population densities in coastal regions are about three times higher than the global average (Small \& Nicholls, 2003). The direct impacts of human activities on the coastal zone have been more significant over the past century than impacts that can be directly attributed to observed climate change (Scavia et al., 2002; Lotze et al., 2006). The major direct impacts include drainage of coastal wetlands, deforestation and reclamation, and discharge of sewage, fertilizers and contaminants into coastal waters.

There are both positive and negative impacts. Coastal erosion is very important in various ways. It provides the beach with sediments which mostly come from the rocks and their related landforms. Without sea erosion, many of the world's biologically productive bays, estuaries, salt marshes and tidal flats would not exist. Erosion of glacial landforms, for instance, provides the primary source of sand and cobble for the beaches in temperate coastlines (Labuz, 2015). It is also responsible for most of the beautiful sceneries in coastal communities that attract tourism including landforms. Some of these landforms are very common along the coastline under study. Notwithstanding how beneficial coastal erosion may be, it is also not out of place to say that it is considered a major economic problem in most coastal communities. One of the effects is the recession of shoreline and loss of beaches. It is not easy to quantify the impact of coastal erosion, shoreline change and beach loss as they affect the coastal zone in various ways.

A lot of coastal communities are counting their losses to coastal erosion and beach loss. It ranges from destruction of property, physical structures, inundation of hitherto dry lands, loss of lives, contamination of fresh water and destruction of the aesthetic values of the coastal zone. For example, in Massachusetts, hundreds of millions of dollars of shorefront real estate is at risk due to both chronic, long-term erosion of coastal bluffs and episodic, short-term induced erosion of dunes and barrier beaches (O'Connell, 2002). Most sand is transported from inland through rivers and streams. Sand can also be transported from beach to beach along a shoreline but this is mostly just a redistribution of sand that is already on the beach. Thus through erosion and accretion, the 
beach looses and gains sediments. In areas where these processes have caused vast movements in the shoreline, especially shoreline advancement, sea defenses and other strategies are used to manage such a condition. In Ghana for instance, a lot of strategies have been used to manage the impact of sea erosion along the beaches of Keta, Ada, Tema, Prampram, Accra, Cape Coast, Elmina, Shama, Sekondi, Takoradi and Nkontompo. These are sea defenses of various kinds but their effectiveness in managing the situation depends on the extent of erosion, accretion and net shoreline movements.

\section{Materials and Methods}

\subsection{The Study Area}

The study area is the coastal stretch between Bortianor and Winneba in the Greater Accra and Central Regions of Ghana respectively. Bortianor is located on latitude $5^{\circ} 31^{\prime} \mathrm{N}$ and longitude $0^{\circ} 20^{\prime} \mathrm{W}$. Winneba on the other hand is located on latitude $5^{\circ} 21^{\prime} \mathrm{N}$ and longitude $0^{\circ} 37^{\prime} \mathrm{W}$. The rationale for selecting this study area, as has been said earlier, is due to the fact that not much seem to have been done in terms of research relating to erosion, accretion and shoreline change and protection in this particular stretch. It is also not part of the Ministry of Water Resources, Works and Housing's (MWRWH, 2010) highest prioritized coastal erosion projects, possibly due to the fact that the extent of erosion and accretion may not have been highlighted enough, although the inhabitants have copiously complained of eminent threat to life and property (through community interaction by this author). This study is therefore meant to unravel the extent of movements in the shoreline so as to inform policy implementers the appropriate measures to take to protect this coastline.

According to Armah (2005), the coastal zone of Ghana may be divided into three geomorphologic zones: West Coast, $95 \mathrm{~km}$, fine sand, gentle beaches, coastal lagoons - Central Coast, $321 \mathrm{~km}$, embayed coast of rocky headlands, rocky shores, littoral sand barriers, coastal lagoons. - East Coast, $149 \mathrm{~km}$, sandy beaches, deltaic estuary of Volta River situated halfway in-between. This study area falls within the central coastline which is mainly made of both sandy and rocky lithoral coastal environment. Although the area falls within the central coastline stretch, different geology are encountered as one traverses along the stretch. The coastal area along Senya Bereku is mainly rocky while that of Woarabeba through Nsuekyir to Winneba is mainly sandy. It is therefore important to examine the extent to which the differences in lithology accounts for the movements in shoreline. It is also true to state that the responses to curb and control shoreline movements resulting from accretion and erosion will differ in time and location. The extent of wave erosion and accretion was assessed with reference to shoreline movements that is advance and retreat of the shoreline. A period of 20 years, from 2000 to 2020, was selected for this study. This helps to assess shoreline movements within short, medium to long-term and episodic in nature as described by (Gibeaut, et al; 2001). Figures 1 and 2 are the map of the study area.

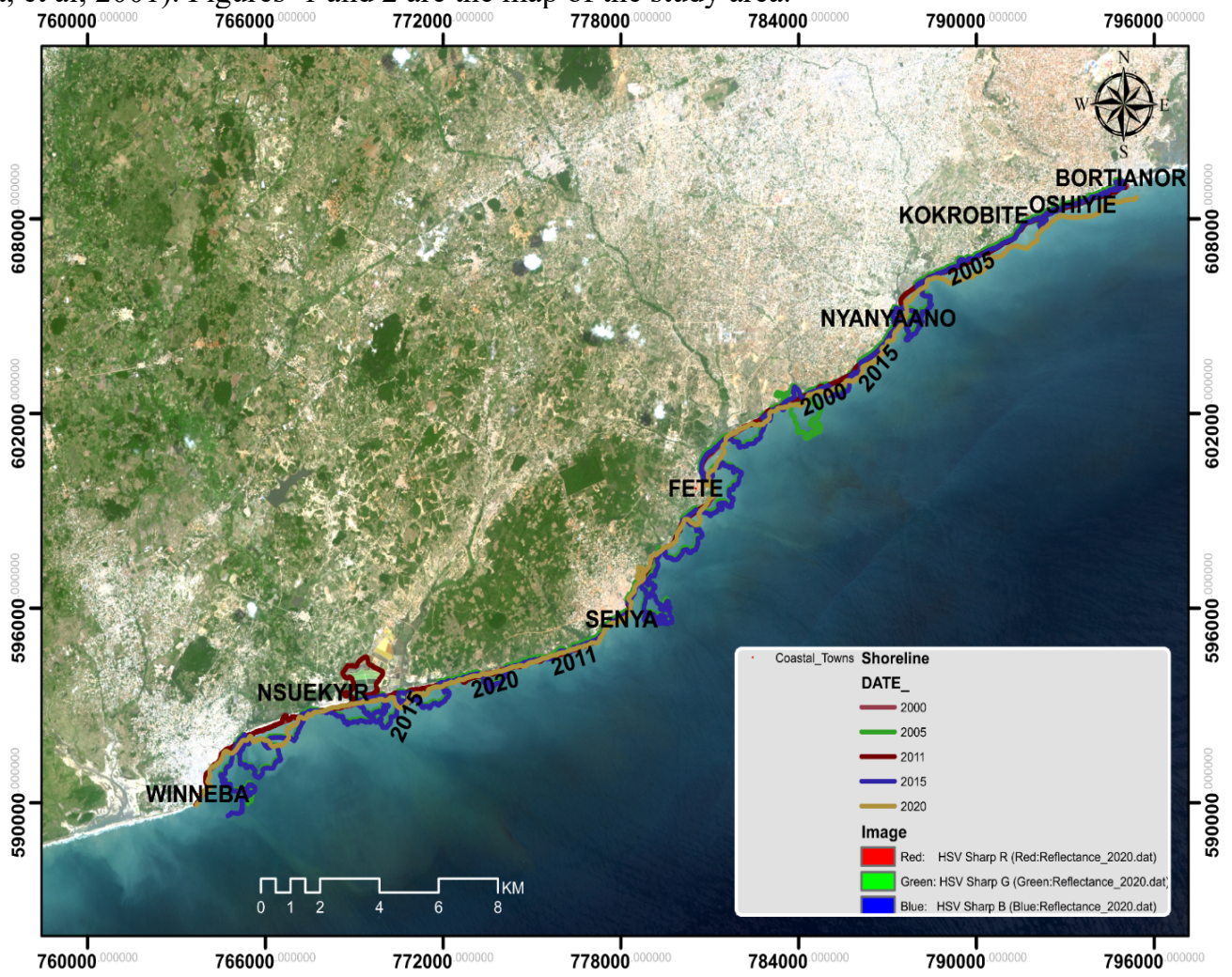

Figure 1: Map of the study area 


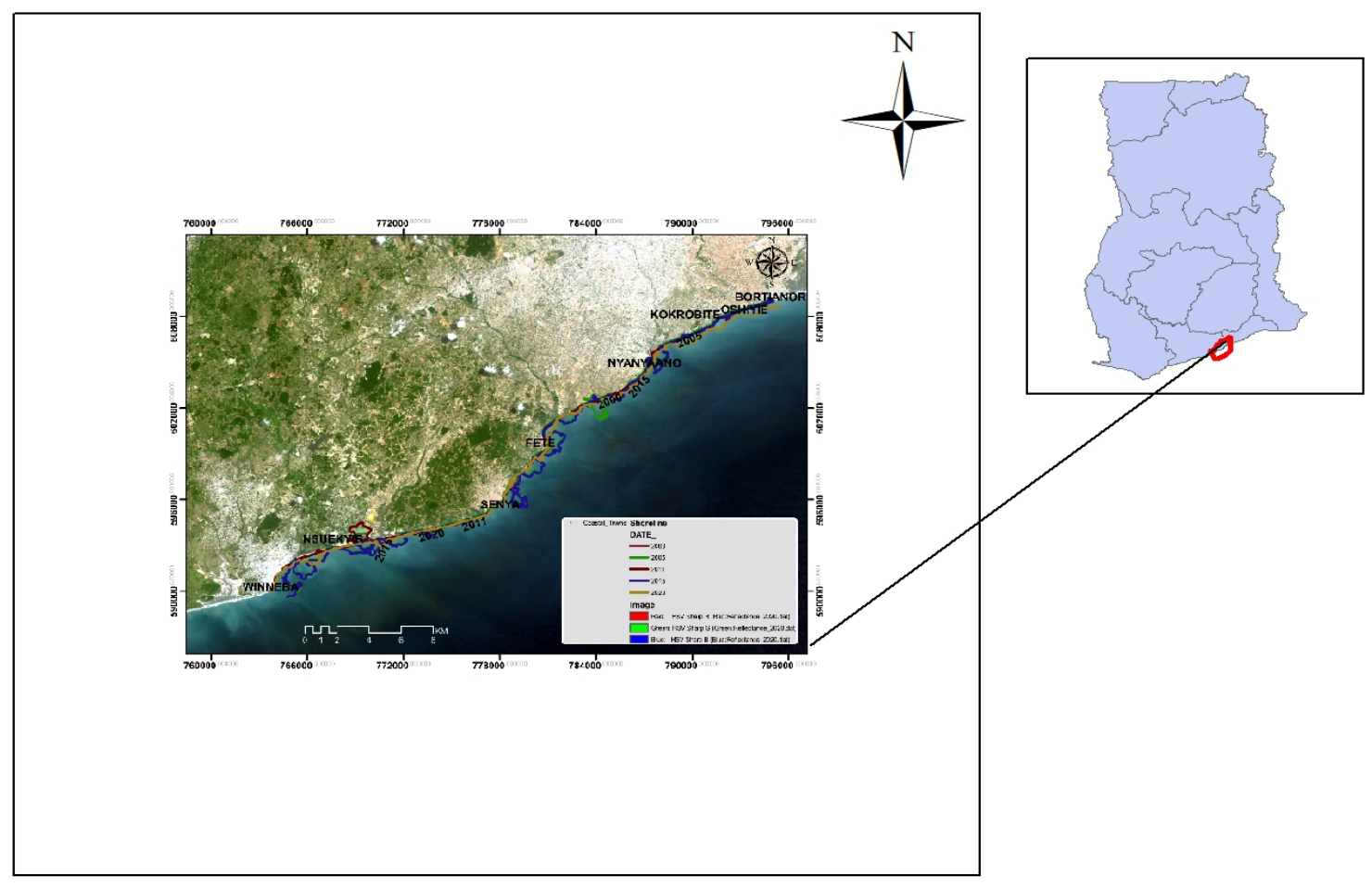

Figure 2: The study area in the context of Ghana

\subsection{Data and Data Acquisition}

The data used for this study were of three types. They include Global Positioning System (GPS) location of ground control point, which is a point referencing data used for geometric calibration of satellite images. The second data was a very high resolution aerial imagery (20 centimeters spatial resolution) captured in October-November 2014, which was also used as reference data. The third data sets used for the positions of shoreline and detection of the shoreline change was Landsat 7 and 8 images. Table 1 provides a detail summary of the images, including image acquisition data, spatial resolution, row and path, imaging sensor and the source of images.

Table 1: Details of the satellite images used in the study

\begin{tabular}{|l|l|l|l|l|l|l|}
\hline Data & Date & Resolution & Row/Path & Sensor & Source & Cloud Cover \\
\hline LE07_L1TP & $04 / 02 / 2000$ & 30 meters & 193056 & Thematic Mapper & USGS & $0 \%$ \\
\hline LE07_L1TP & $01 / 02 / 2005$ & 30 meters & 193056 & Thematic Mapper & USGS & $0 \%$ \\
\hline LE07_L1TP & $17 / 01 / 2011$ & 30 meters & 193056 & Thematic Mapper & USGS & $0 \%$ \\
\hline LC08_L1TP & $15 / 03 / 2017$ & 30 meters & 193056 & OLI / TIRS & USGS & $0 \%$ \\
\hline LC08_L1TP & $13 / 02 / 2020$ & 30 meters & 193056 & OLI / TIRS & USGS & $0 \%$ \\
\hline
\end{tabular}

Satellite images and aerial photographs covering such periods were derived for each of the selected areas. The study assessed the longitudinal profile of accretion and erosion along the study coastline and supplemented that with snap-checks at some selected points along the coastline. The locations of the snap-checks include Bortianor, Nyanyaano, Senya Bereku, Fete, Nsuekyir and Winneba. The snap points were used for point analysis. These were used to determine the shoreline movements along the selected coastlines through Digital Shoreline Analysis System (DSAS).

\subsection{Data Preprocessing and Analysis}

The satellite images were radiometrically calibrated, stacked and converted to Envi standard image format. Software used in this study include ENVI 5.3 and ArcGIS Desktop 10.7.1. The panchromatic band of the Landsat images was used to pan sharpen the images to 15 meter resolution using the bilinear resampling method. This was to help sharpen the image to define the line between the water and the land. Using the 2005 image as the base image, all the images were registered to geometrically align each image into the same coordinate system so that the corresponding pixels would represent the same object. Unsupervised classification of two classes was then performed to separate water from land. The result was saved as Shapefile and exported to ARCGIS Desktop. The Shapefile was then converted from polygon to line and the shoreline was then highlighted and exported to a different Shapefile. ArcGIS editing tools were used to clean the data.

ArcGIS add-on software, Digital Shoreline Analysis System (DSAS) version 5 was used for the data processing. Attribute were added to the shoreline data extracted according to the demands of DSAS. The attribute 
added includes date, uncertainty, shape length and shoreline type in addition to the default system attribute like shape and object ID. Fields such as date and shape length were populated and all shorelines were merged into one feature class in a personal geodatabase.

The merged shoreline data was buffered at 150 meters using the flat line-end-type. The onshore segment off this buffer was digitized using ArcGIS editing tools. With the shoreline and baseline data in a personal database, the default parameters of the DSAS add-on was then set using the seaward intersection option. Transects were generated using a maximum search distance of 2040 meters from baseline and 200 meters transect spacing. The use of DSAS to calculate end point rate of shoreline movements had also been employed in similar studies undertaken by, Fikir et al (2014), Dadson, et al; (2016) and Jonah et al, (2016). Change statistics was computed using the generated transect. The statistics that were computed were shoreline change Envelope, Net Shoreline Movement, End Point Rate and Linear Regression Rate.

Shoreline Change Envelope (SCE) was used to measure the total change in shoreline movement considering all available shoreline positions and reporting their distances, without reference to their specific dates.

Net Shoreline Movement (NSM) shows the distance between the oldest and the current shorelines.

The end point rate was calculated by dividing the distance of shoreline movement by the time elapsed between the two shorelines. The rate is reported in meters per year with positive values indicating accretion and negative values indicating erosion.

Linear regression was used to model the relationship between two variables (in this case accretion and erosion) by fitting a linear equation to observed data. It was used because the study wanted to know and predict the value of change based on erosion or accretion.

\section{Results and Discussion}

For the purpose of good visualization, easy comparison and better understanding, the results of the shoreline analysis was presented in segments. The study covers the coastline from Bortianor in the Weija-Gbawe Municipal Area of the Greater Accra Region to Winneba in the Effutu Municipal Area, Central Region, Ghana (Figure 3). The first segment stretches from Bortianor to Nyanyaano, the second segment covers Nyanyaano to Fete, the third extends from Fete to Senya, the fourth is from Senya to Nsuekyir and finally, the fifth segment is from Nsuekyir to Winneba. Though the analysis and results are discussed based on the locational segments above, it is also done based on the main objectives of the study. The use of very high, high, moderate, etc in the discussion is relative to the legend as used in the maps.

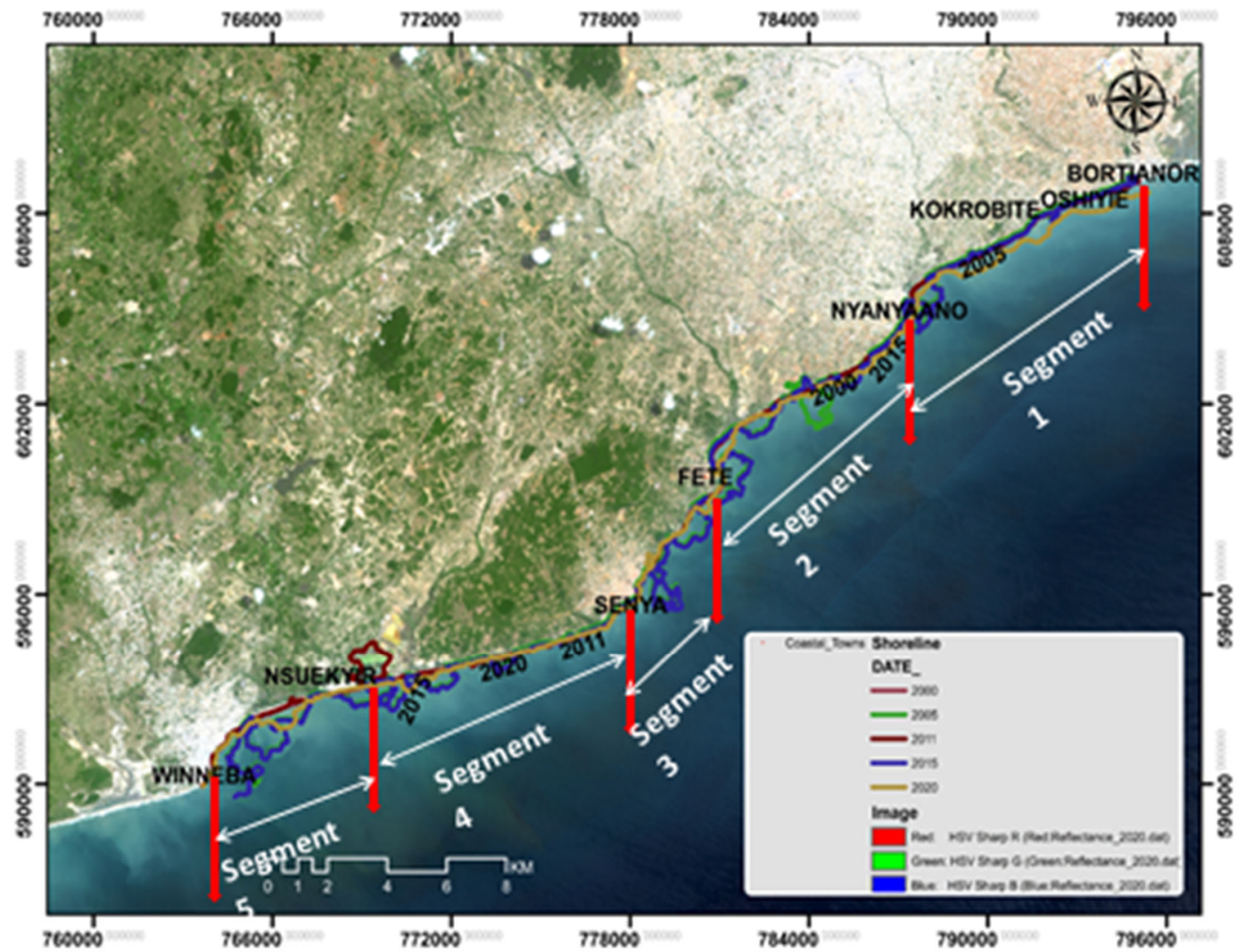

Figure 3: Study area divided into segments for analysis 
Segment 1: The stretch from Bortianor to Nyanyaano - This segment of the study area experienced accretion throughout the study period than erosion (Figure 4).

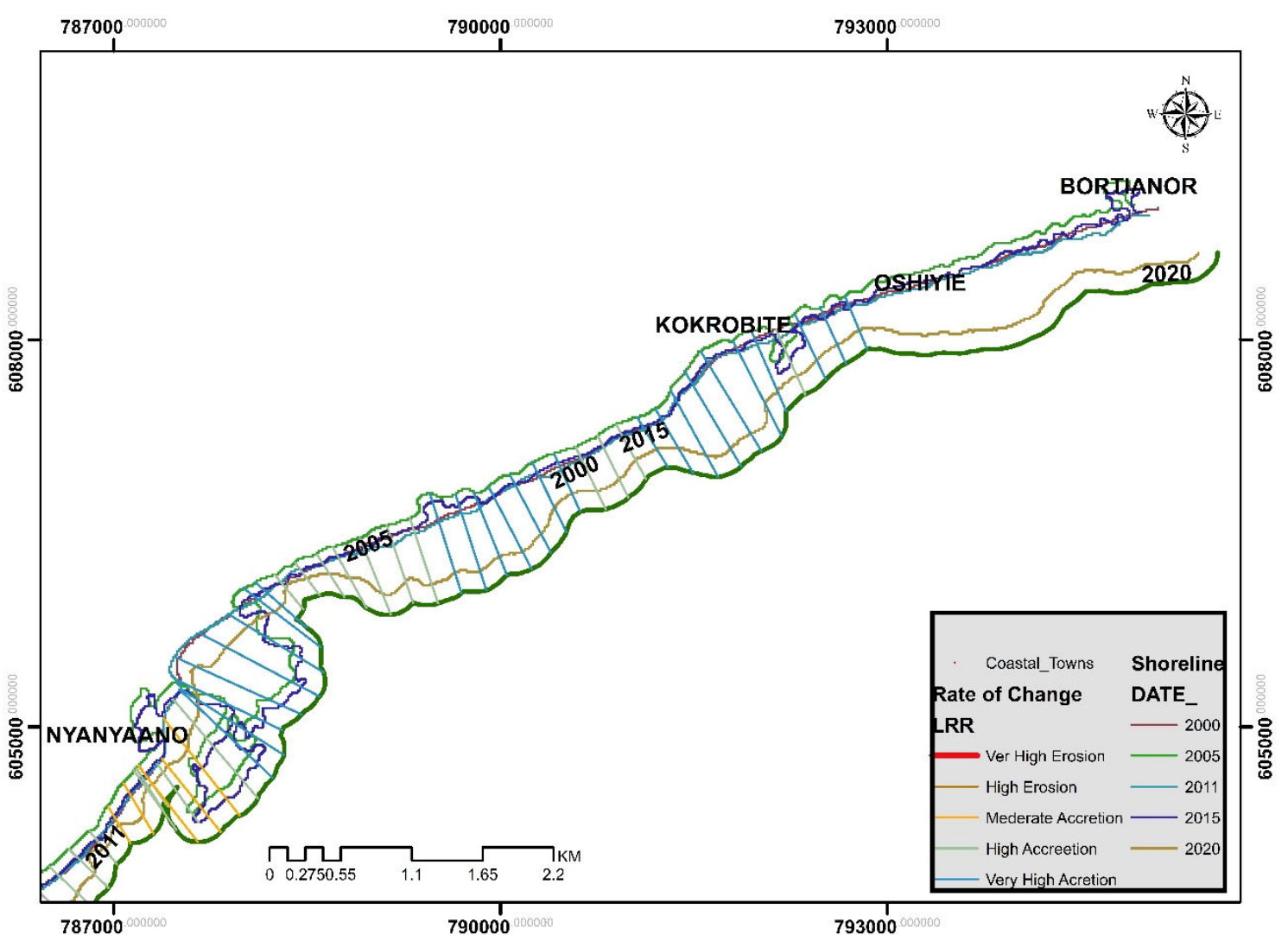

Figure 4: Shoreline from Bortianor to Nyanyaano

This is reflected in the general shoreline position from 2000 through to 2020. This notwithstanding, there are differences in rates of erosion. Areas around Nyanyaano, especially the western part experienced the highest rate of erosion. In other words, the area from Bortianor through Kokrobite to the eastern side of Nyanyaano experienced moderate erosion but very high rate of accretion throughout the study period. The average NSM was $81.38 \mathrm{~m}$ while the EPR was $3.96 \mathrm{~m} / \mathrm{y}$. What this means is that within the study period from the year 2000 to 2020 , the shoreline fluctuation, mainly through accretion was $81.38 \mathrm{~m}$ but the average rate of shoreline movement, mainly shoreline retreat was 3.96 meters per year, especially from the year 2005. Thus, since 2005, the shoreline has generally been retreating than advancing. There were few fluctuations in the shoreline positions, around Nyanyaano due to the significant continuous and alternating erosion and accretion as it happens along every coastline. The reasons for the high erosion around Nyanyaano may be explained in relation to the curvy and sandy nature of the coastline. The broad and relatively flat coastal landscape from Bortianor through Kokrobite with alternating vegetation, including mangroves as described by Mensah, Fosu-Menash and Yirenya-Tawiah (2014) may have accounted for the generally high accretion rate and coastal retreat. The broad and relatively flat coastal landscape or beach makes the waves spread and break-off while the vegetation serve as barrier, reducing the speed of the waves before reaching the shore. 
Segment 2: Nyanyaano to Fete. This segment has a complete mix of erosion and accretion. Figure 5 shows the segment.

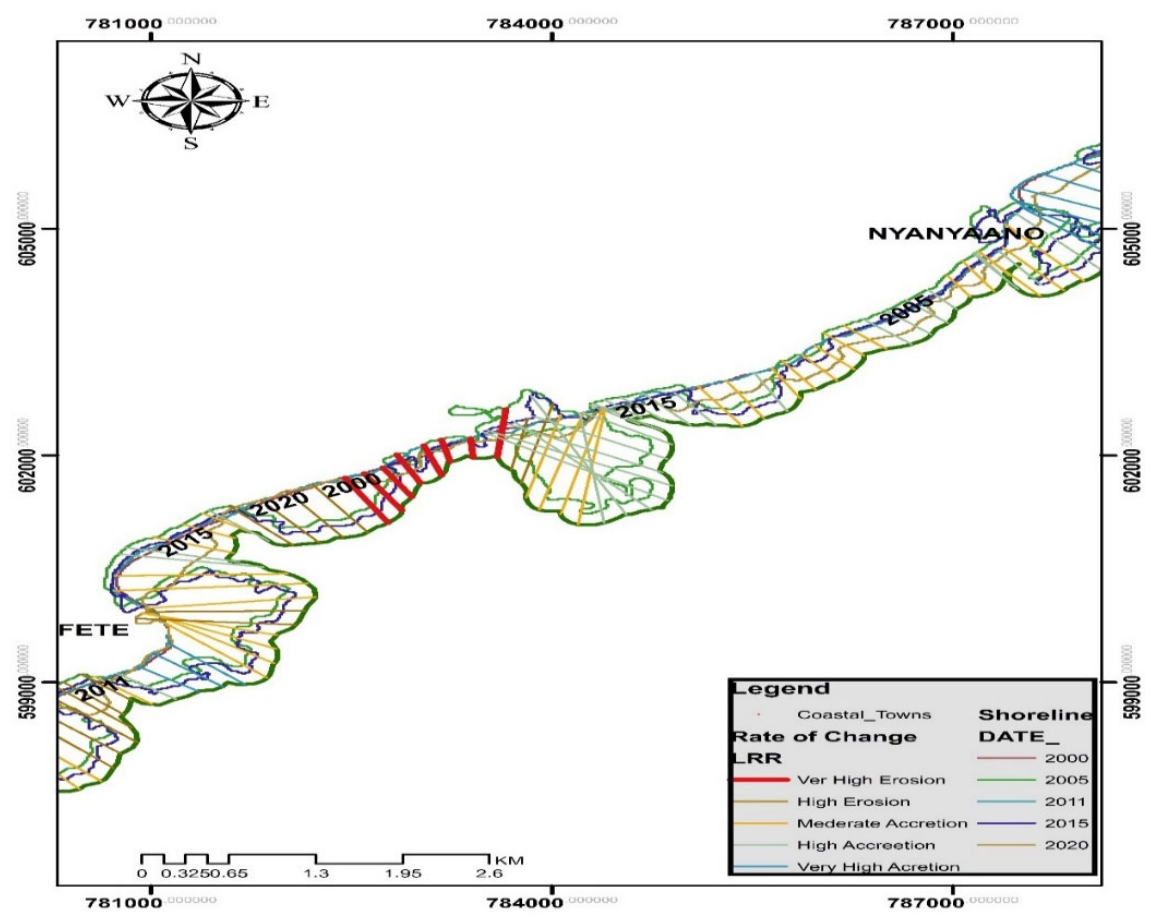

Figure 5: Shoreline movements along Nyanyaano and Fete coastline

This shoreline is generally characterized by high to moderate accretion with few areas experiencing very high erosion. The western side of Nyayaano experienced moderate to high accretion around 2005 with a retreat of the shoreline. Prior to this, there was very high erosion in the year 2000 with NSM of $-197.37 \mathrm{~m}$ which occurred on the eastern side of Fete but the entire shoreline did not experience any massive advancement, with the exception of few narrow strip, which experienced significant advancement in shoreline of $-9.61 \mathrm{~m} / \mathrm{y}$. This is mainly due to the rocky nature of the coastline, which is made of igneous and metamorphic lithology (Dei 1975). The few areas with massive advancement are those with patches of sand and probably easily eroded rocks. In all, Fete and its immediate surroundings rather experienced moderate to high accretion.

Segment 3: Fete to Senya. In this segment there is generally moderate to very high accretion along the coast.

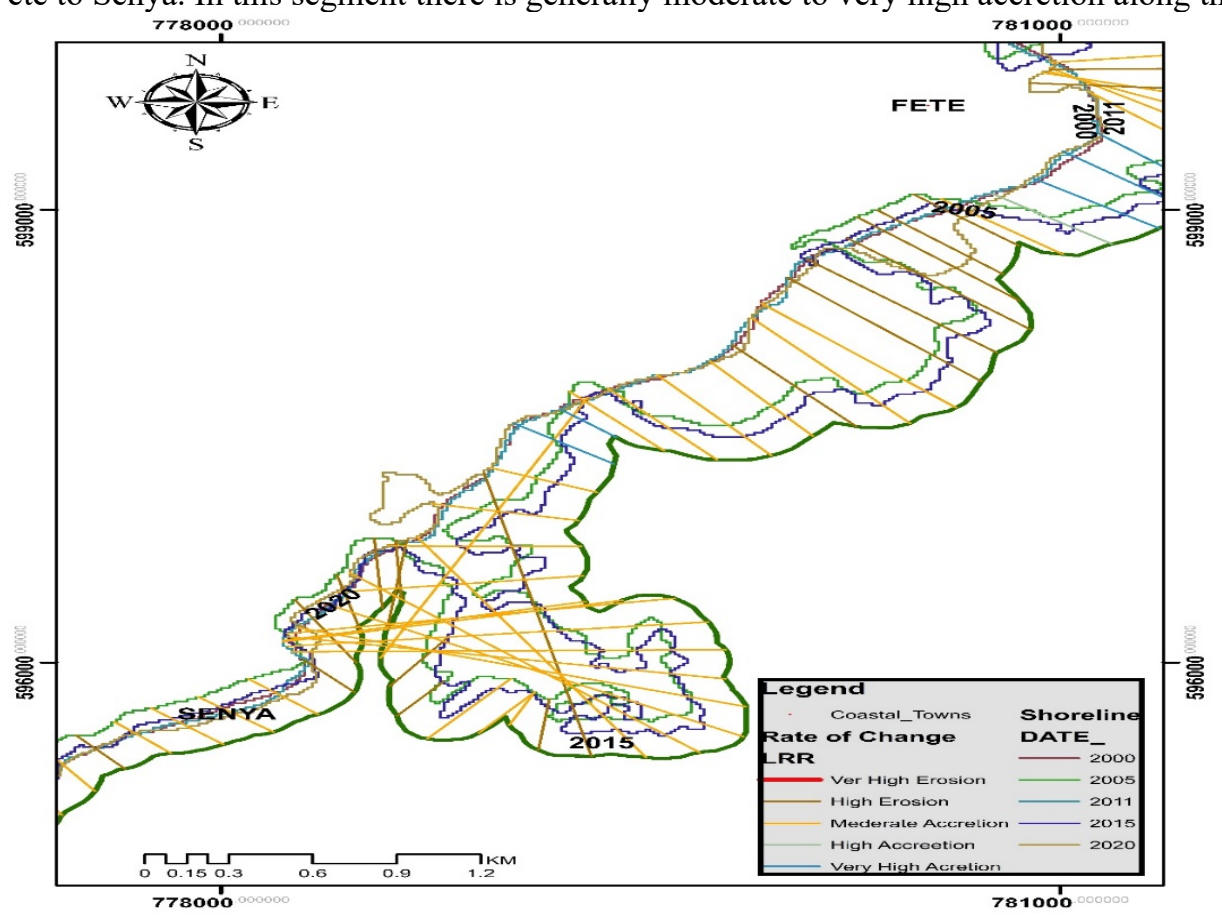

Figure 6: Shoreline movements along Fete and Senya coastline 
At the extreme east of Fete, there was high to very high accretion between 2011 and 2000. This is followed by moderate accretion towards the western side. This observation could be possibly attributed to the high resistant rocky coast, as described by (Dei, 1975). In his description of the coastline of Ghana, Dei (1975) indicated that the coastal segment between Fete and Senya is rocky and steep and very resistant to coastal erosion. Though the coast is curvy, the rocky lithology and the coastal orientation reduce the impact of the waves from attacking the beach.

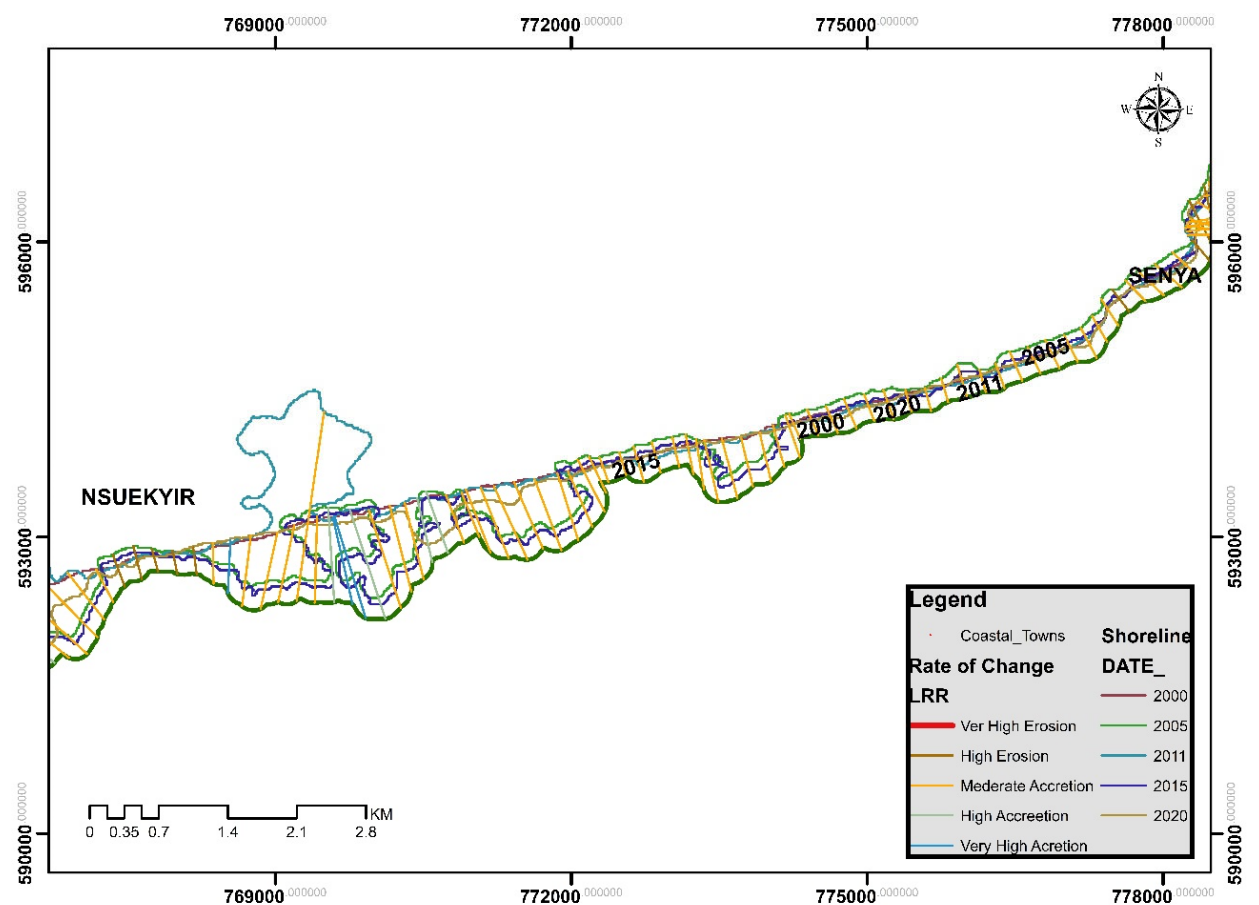

Figure 7: Shoreline movements along Senya and Nsuekyir coastline

There was generally moderate to high accretion which did not bring any massive shift in the shoreline positions. The shoreline was therefore characterized by more retreat than advancement. Thus the shoreline movement is mainly sort-term and episodic in nature Gibeaut, et al; (2001), probably by occasional storm surge and huge sand deposit.

Segment 5: Nsuekyir to Winneba

This coastline is mainly associated with very high accretion in mid-way between Nsuekyir and Winneba. The eastern part of Winneba and the immediate western part of Nsuekyir experienced moderate accretion throughout the study period. The retreat of the shoreline has been massive along the coast.

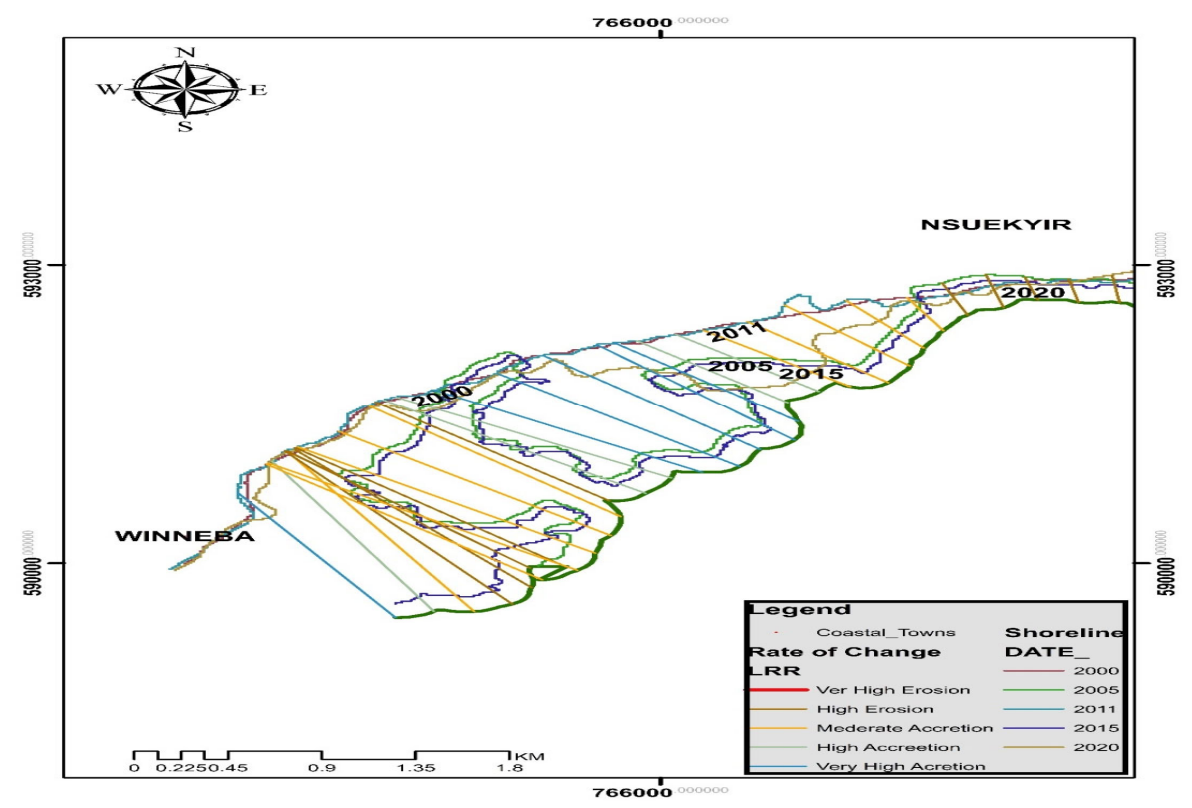

Figure 8: Shoreline movements along Nsuekyir and Winneba coastline 
The entire coastline experienced accretion and hence, shoreline retreat throughout the study period. This could be due to the broad and open nature of the beach, which allows the waves to spread the water along the beach as the materials are gradually deposited. Due to the continuous rate of accretion, coastal areas from Woarabeba, through Nsuekyir to the Winneba beach has over the years retreated and this has resulted in the development of a raised beach. Figures 9 and 10 give further details in the extent of erosion and accretion and hence NSM within the area.

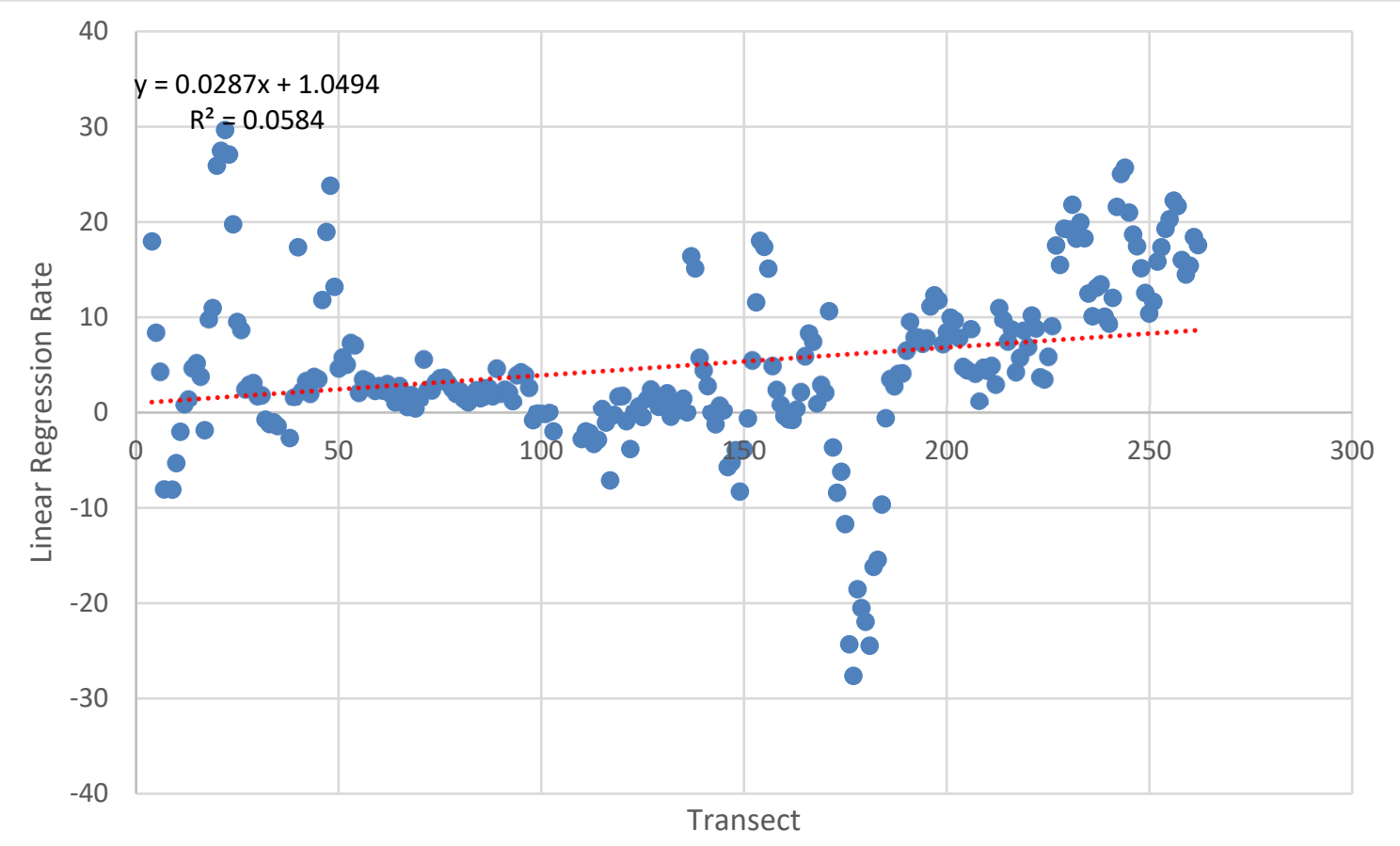

Figure 9: Linear regression for estimating the rate of erosion and accretion

The linear regression analysis also shows a general trend of accretion than erosion. The extreme east and west of the study area experienced very high accretion, hence the shorelines in these areas reveal high level of retreat. The middle portions generally experienced moderate accretion, yet the eastern portion of Fete experienced very high erosion.

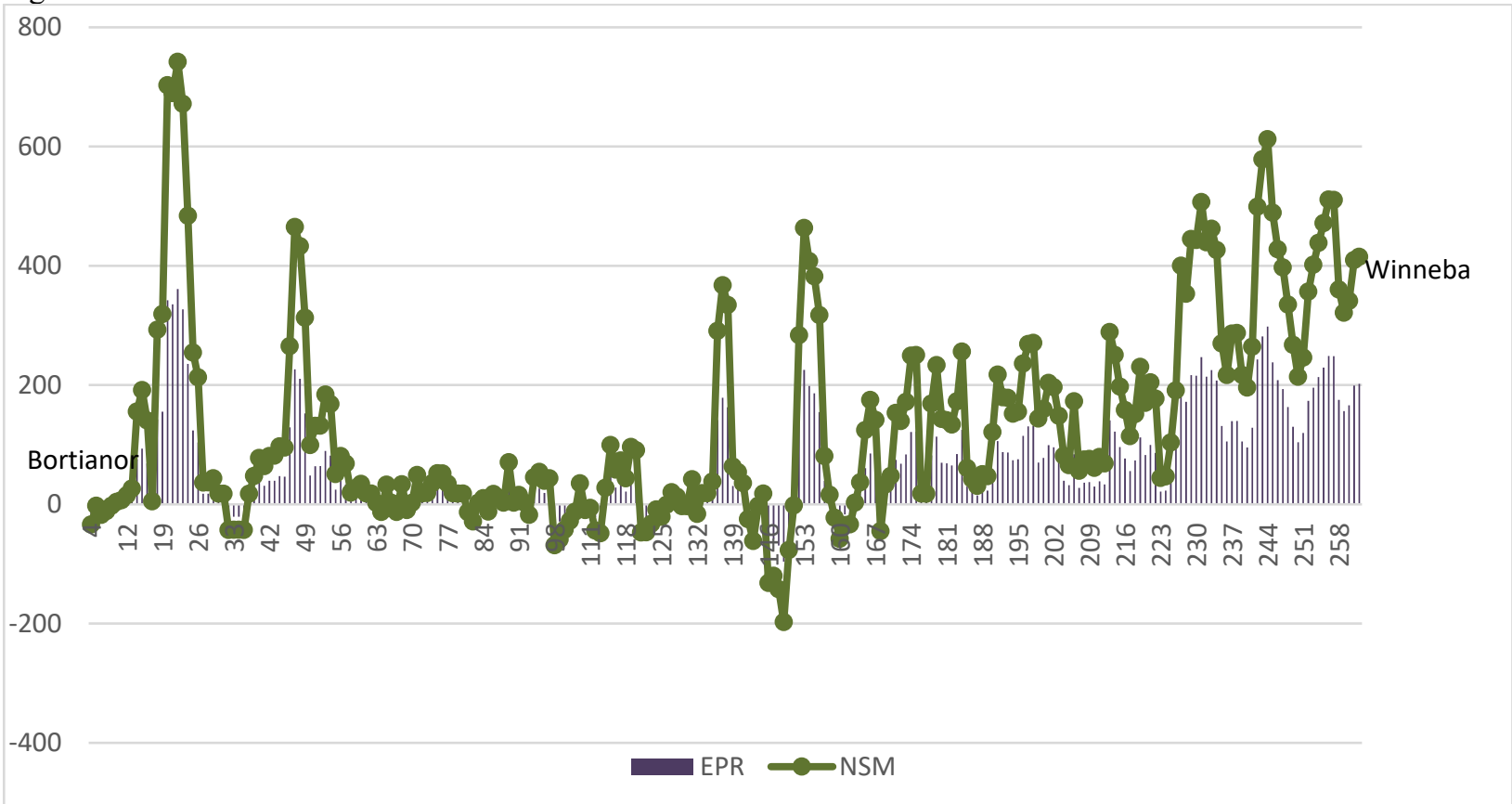

Figure 10: NSM from Bortianor to Winneba Shoreline

A section of the study area between Nyanyaano and Fete experienced extreme erosion with higher rate of shoreline advancement whereas most part experienced higher rate of accretion with very high rate of shoreline 
retreat. The highest rate of shoreline retreat occurred at Bortianor with NSM value of $741.92 \mathrm{~m}$ and an EPR of 36.11. The highest rate of shoreline advancement occurred at Fete with a NSM value of -197.37 with an EPR of $9.61 \mathrm{~m} / \mathrm{y}$. This is due to very high rate of erosion.

Table 2: Average NSM and EPR within each segments in the study area

\begin{tabular}{|l|l|l|l|}
\hline SEGMENTS & NSM (m) & EPR $(\mathbf{m} / \mathbf{y})$ & DESCRPTION \\
\hline Bortianor -Nyayaano & -2.64 & -0.13 & Moderate erosion \\
\hline Nyanyaano -Fete & 81.35 & 3.96 & High accretion \\
\hline Fete - Senya & -68.59 & -3.34 & High erosion \\
\hline Senya - Nsuekyir & -33.6 & -1.64 & High erosion \\
\hline Nsuekyir - Winneba & 245.85 & 11.97 & Very high accretion \\
\hline
\end{tabular}

From Table 2, it could be deduced that the coastal segments between Bortianor and Nyanyaano, Fete and Senya and from Senya to Nsuekyir experienced moderate to high rate of erosion, hence the shorelines experienced an advancement with the highest occurring between Fete and Senya. On the other hand, the segment from Nyanyaano to Fete and Nsuekyir to Winneba experienced high rate of accretion. The open nature of these beaches may have accounted for the high rate of accretion with huge sand deposit and significant shoreline retreat.

\section{Conclusions}

The shoreline under study shows a general unstable position as with any other coastline. This is due to continuous accretion and erosion. Generally, there is a continuous trend of retreat than advancement due to increasing high rate of accretion. With the exception of Senya and Fete, most part of the coastline is made of sandy characteristics; hence it is not strange to see more sand deposition. It is therefore concluded that the area does not show any serious threat of an advancing shoreline. As a result, one is not surprised that it is not included in the national sea defense project. It can be referred to as short-term and episodic movements as espoused by Gibeaut, et al; (2001). This notwithstanding, there should be continuous monitoring of the behaviour of wave action with regards to erosion and accretion so that immediate and appropriate action can be taken to manage the outcome of these coastal dynamic processes.

\section{Policy Implications}

The study tried to analyse the shoreline positions and the rate of movements between the selected years and the selected locations. The dynamics that lead to fluctuations in the position and movements of shorelines were identified as erosion and accretion. The shoreline understudy did not suffer much erosion but there had been moderate to very high accretion along the beaches. This information is important since it helps to inform policy makers on the nature of the coastlines, their dynamics and the kind of actions that need to be taken. There is need for constant monitoring of these coastlines since there is the tendency to overlook it since accretion seems to be more accommodating to coastal dwellers and policy makers than erosion. This notwithstanding, the few areas that were identified with high erosion could be managed immediately so as to halt the impact it would have on other locations. The study therefore highlights the state of shoreline in these locations since the area has not seen much research on the subject matter as compared with other coastlines along Ghana. It therefore helps to bring to spotlight the need to put the necessary mechanisms in place to protect this shoreline in order not to encounter the worse situations that have occurred in some other locations along the Ghanaian coastline. It is thus a wake-up call for action by policy makers, especially the Ministry of Water Resources Works and Housing to consider some areas in this coastal stretch in the national sea defense project.

\section{References}

Alesheikh, A. A., Ghorbanali, A. \& Nouri, N. (2007). Coastline change detection using remote sensing. International Journal of Environment, Science and Technology 4 (1): 61-66, 2007.

Angnuureng, D. B., Almar, R., Appeaning Addo, K., Castelle, B., Senechal, N., Sowah W. L, \&

Armah A. K. (2005) Vulnerability and adaptation assessment training workshop 18-22 April, 2005 Maputo, Mozambique.

Boye, C. B., Appeaning Addo, K., Wiafe, G., \& Dzigbodi-Adjimah, K. (2018). Spatio-temporal analyses of shoreline change in the Western Region of Ghana. Journal of Coastal Conservation. (22), 769-776.

Boateng, I. (2012). An application of GIS and coastal geomorphology for large scale assessment of coastal erosion and management: a case study of Ghana. J Coast Conserv 16, 383-397.

Dadson I. Y., Owusu A. B \& Adams O, (2016). Analysis of Shoreline Change along Cape Coast-Sekondi Coastline, Ghana. Geography Journal Vol 2016 Article ID1868936, 9 pages.

Dale, F. R., Kochel R. C., \& Miller J. R. (1995). Process geomorphology $3^{\text {rd }}$ ed. Dubuque IA, USA: WCB Wm. C. Brown Communications Inc.

Dei, L. A. (1975). Morphology of the rocky shoreline of Ghana. Bulletin of the Ghana Geographical Association. Vol. 17 pp. 1-30. 
Evadzi, P.I.K., Zorita, E., and Hünicke, B. (2017). Quantifying and predicting the contribution of sea-level rise to shoreline change in Ghana: Information for coastal adaptation strategies. Journal of Coastal Research, 33 (6): 1283-1291.

Fikir, A., Onwonga, R., Mwangi J.K., \& Wasonga, O. (2014). Assessment of Shoreline Changes in the Period 1969-2010 in Watamuarea, Kenya. Global Journals Inc. (USA). (14)6.

ISSN: 22494626 \& Print ISSN: 0975-5896.

Gibeaut, J. C., Hepner T., Waldinger, R., Andrews, J., Gutierrez, R., Tremblay T. A., \& Smyth R. (2001). Changes in gulf shoreline position, Mustang and North Padre Islands, Texas. A report of the Texas Coastal Coordination Council pursuant to National Oceanic and Administration.

Heinz Center, (2000). The hidden costs of coastal hazards: Implications for risk assessment and mtigation. A multisector collaborative project of the H. John Heinz Center for Science, Economics, and the Environment. Island Press.

Jonah, E. F., Abeashi Mensah, E., Edziyie,E. R., Agbo, N. W., \& Adjei-Boateng, D. (2016). Coastal Erosion in Ghana: Causes, Policies, and Management, Coastal Managemen, (44)2, 116-130

Jonah, F. E., Boateng, I., Osman, A., Shimba, M. J., Mensah, E. A., Adu-Boahen, K., Chuku, E. O., \& Effah, E. (2016). Shoreline change analysis using end point rate and net shoreline movement statistics: An application to Elmina, Cape Coast and Moree section of Ghana's coast. Regional Studies in Marine Science. (7) 19-31 https://doi.org/10.1016/j.rsma.2016.05.003.

Kuhn, G. G., \& Shepard, F. P. (1983). Beach processes and sea cliff erosion in Sandiego County; Carlifornia. In CRC handbook of coastal processes and erosion, edited by P. Kommar, pp. 267-84. Boca Raton, Fla; CRC Press.

Łabuz T.A. (2015) Environmental Impacts - Coastal Erosion and Coastline Changes. In: The BACC II Author Team (eds) Second Assessment of Climate Change for the Baltic Sea Basin. Regional Climate Studies. Springer, Cham. https://doi.org/10.1007/978-3-319-16006-1_20

Lotze, H. K., Lenihan, H. S. Bourque, B. J. Bradbury, R. H. Cooke, R. G. Kay, M. C. Kidwell, S. M., Kirby M. X., Peterson, C. H. \& Jackson, J. B. C. (2006). Depletion, degradation and recovery potential of estuaries and coastal seas Science.

May, S. K., Dolan, R., \& Hyden, B. P. (1983). Erosion of US shorelines. EOS64: 521-23.

Mensah M; Fosu-Mensah, B. Y. and Yirenya-Tawiah, D. (2014). Assesing public perception of beach quality for ecotourism development: A case study in Kokrobite beach in the Greater Accra Region, Ghana. Journal of Environment and Earth Science. ISSN 2224-3216. Vol.4, No.11, 2014.

Ministry of Water Resources, Works and Housing (2010) Sea Defense and Erosion Projects, Ghana (NBCC, n.d. http://www.nationalbcc.org/resources/contracting/1299-sea-defense)

Oteng-Ababio, M., Owusu, K., \& Kwasi Appeaning Addo, K. (2011). The vulnerable state of the Ghana coast: The case of Faana-Bortianor. Journal of Disaster Risk Studies, (3)2.

Scavia, D. J. C., Field, D. F., Boesch, R., Buddemeier, D. R., Cayan, V., Burkett, M. Fogarty, M. Harwell \& Coauthors. (2002). Climate change impacts on U.S. coastal and marine ecosystems. Estuaries management. 64 (3) 23.45 .

Small, C. \& Nicholls R. J. (2003). A global analysis of human settlement in coastal zones. J. Coastal Res.

UNEP/UNDP (2012). Ghana national Climate Change Adaptation Strategy. Retrieved 28/03/14 from www.undpalm.org/recources/naps-non-least-developed-countries-non-ldcs/ghanas-national-climate-changeadaptation-strategy.

Valiela, I. (2006). Global coastal change. Blackwell, Oxford.

Waugh D. (1995) Geography; An Integrated Approach, UK: Thomas Nelson \& Sons ltd

Wiafe, G. (2016). Video Observation of Waves and Shoreline Change on the Micro-tidal James Town Beach in Ghana. Journal of Coastal Research (75)1022 - 1026. 